\title{
Social Exclusion of People Who Suffer from Mental Disorders: A Proposal for an Explanatory Model
}

\author{
Silvana Carneiro Maciel ${ }^{1}$ (1) https://orcid.org/0000-0003-1489-1126 \\ Cicero Roberto Pereira ${ }^{1,2}$ (D) https://orcid.org/0000-0003-3406-3985 \\ Tiago Jessé Souza de Lima ${ }^{3}$ (1) https://orcid.org/0000-0001-8840-4285 \\ Luana Elayne Cunha de Souza ${ }^{3}$ @ https://orcid.org/0000-0001-9425-9598 \\ Leoncio Camino ${ }^{1}$ (i) https://orcid.org/0000-0002-8666-7898 \\ Giselli Lucy Souza Silva ${ }^{1}$ (1) https://orcid.org/0000-0002-0604-6398
}

\begin{abstract}
Beliefs about the nature of social groups may motivate people to exclude members of minority groups from their conviviality. This process is analyzed in this article by proposing an explanatory model for the social exclusion of people suffering from mental disorders wherein beliefs about the nature of mental disorder, the perception of threat and prejudice contribute to social exclusion. Two studies (Study 1, $N=254$; Study 2, $N=236$ ) were conducted with university students who answered the following questions about beliefs and prejudices regarding mental disorders, perceived threat and social exclusion. Regression analyses have shown that exclusion is motivated by prejudice, whose impact is mediated by perceived threat. The results also indicated that prejudice is anchored in participants' beliefs on the nature of mental disorders, especially those with a religious basis.
\end{abstract}

Keywords: Mental disorders, beliefs, prejudice, social exclusion

\section{Exclusão Social de Pessoas que Sofrem com Transtornos Mentais: Uma Proposta de Modelo Explicativo}

\begin{abstract}
Resumo: As crenças sobre a natureza dos grupos sociais podem motivar as pessoas a excluírem membros de grupos minoritários do seu convívio. Este artigo analisa esse processo propondo um modelo explicativo da exclusão social de pessoas que sofrem com transtornos mentais no qual as crenças sobre a natureza do transtorno mental, a percepção de ameaça e o preconceito contribuem para a exclusão social. Para tanto foram realizados dois estudos (Estudo 1, $N=254$; Estudo 2, $N=236$ ) com estudantes universitários que responderam os seguintes perguntas sobre crenças e preconceito acerca dos transtornos mentais, percepção de ameaça e exclusão social. Análises de regressão demonstraram que a exclusão é motivada pelo preconceito, sendo o impacto do preconceito mediado pela percepção de ameaça. Os resultados também indicaram que o preconceito está ancorado nas crenças que os participantes mantêm sobre a natureza dos transtornos mentais, especialmente aquelas de base religiosa.
\end{abstract}

Palavras-chave: Distúrbios mentais, crenças, preconceito, exclusão social

\section{Exclusión Social de Personas que Sufren de Trastornos Mentales: una Propuesta de Modelo Explicativo}

\begin{abstract}
Resumen: Las creencias de las personas sobre la naturaleza de los grupos sociales pueden motivar la exclusión de su convivencia de miembros de grupos minoritarios. El presente artículo analiza este proceso y propone un modelo explicativo de exclusión social de las personas que sufren de trastornos mentales, en que las creencias sobre la naturaleza del trastorno mental, la percepción de amenaza y el prejuicio contribuyen a la exclusión social. Para ello, se realizaron dos estudios (Estudio 1, $N=254$; Estudio 2, $N=236$ ) con estudiantes universitarios que respondieron las preguntas sobre creencias y prejuicios acerca de los trastornos mentales, sobre percepción de amenaza y sobre exclusión social. Los análisis de regresión demostraron que la motivación de la exclusión es el prejuicio, siendo que el impacto del prejuicio es mediado por la percepción de amenaza. Los resultados también apuntan que el prejuicio tiene por base las creencias que mantienen los participantes sobre la naturaleza de los trastornos mentales, especialmente aquellas religiosas.
\end{abstract}

Palabras clave: Trastornos mentales, creencias, prejuicio, exclusión social

\footnotetext{
${ }^{1}$ Universidade Federal da Paraíba, João Pessoa-PB, Brazil

${ }^{2}$ Instituto de Ciências Sociais da Universidade de Lisboa

${ }^{3}$ Universidade de Fortaleza, Fortaleza-CE, Brazil
}

Support: Article derived from the postdoctoral stage of the first author under the supervision of the second, in the period 2013-2014 at the Institute of Social Sciences of the University of Lisbon. With CAPES / FCT / 2642/12/3/201 bag.

Correspondence address: Silvana Maciel. Universidade Federal da Paraíba. Psychology Campus I-Castelo Branco. João Pessoa-PB, Brazil. CEP 58.051-900 E-mail: silcamaciel@gmail.com
As suggested by Foucault (1960/2012), mental disorders are the object of a discourse that describes a complex social image related to prejudice and social exclusion. The discourse about mental disorders was built throughout history, based in explanations linked to evil spirits, organic factors and, most recently, to psychological and social issues. Foucault (1960/2012) points out that, in the late XVIII century, psychiatry postulated that mental disorders were 
illnesses that must be subjected to medical care in psychiatric institutions, isolating the individual from their family and society. From then on, the perception of the mental disorder as an illness has become part of the social representation of madness (Maciel, Barros, Camino \& Melo, 2011).

Nowadays, the discourse regarding people suffering from mental disorders is multifaceted and involves an articulated system of beliefs about the nature of mental disorders (Maciel, Pereira, Lima \& Souza, 2015). These beliefs can form the basis for discriminatory attitudes, as noted by Lacerda, Pereira and Camino (2002). Hence, this study examined beliefs regarding individuals suffering from mental disorders, the perception that they represent a threat, and, more objectively, the relationship between these beliefs and the processes of social exclusion and the curtailment of rights that are reflected in society through the lack of support for policies that promote the social inclusion of these individuals.

Throughout history, people suffering from mental disorders have been subjected to discrimination, separated from their families and isolated from daily social interaction. This phenomenon carries through to the present day, as evidenced by the results of studies on attitudes towards individuals suffering from mental disorders that show that negative attitudes towards mental disorders influence policies and world views (Corrigan, Morris, Michales, Rafacz, \& Rusch, 2012; Evans-Lacko, Henderson, \& Thornicroft, 2013) to such an extent that people suffering from mental disorders are prevented from exercising autonomy over their lives, finding employment, and exercising their basic rights (Pescosolido, Medina, Martin, \& Long, 2013). Such beliefs also reify the idea that those individuals represents a threat to the physical and social integrity of the community (Jodelet, 2005; Nee \& Witt, 2013).

Despite social advances such as the passage of laws guaranteeing the rights of people suffering from mental disorders, inspired by the movement for Psychiatric Reform and Social Inclusion (Alverga \& Dimenstein, 2006; Torre \& Amarante, 2001) there still persists a notably unsatisfactory atmosphere with regard to these persons (Maciel et al., 2011). Stereotypical views and unfavourable feelings with regard to individuals suffering from mental disorders are still found in common sense; an example is the image that individuals have about these people as "lacking good judgement" and being "unreasonable" and "aggressive." These representations are even found among mental health professionals (Arvaniti et al., 2009) because, according to Foucault (1960/2012), these representations are disseminated throughout society and are anchored in years of exclusion and marked by treatment based on labeling, the suppression of symptoms through medicalization, and confinement in mental wards.

These beliefs about mental disorders can be found in negative attitudes about them and in the perception that these individuals represent a threat to society (Pescosolido, 2013). The question that, to date, the specialized literature on this subject has not answered is to what extent these beliefs and perceptions are related to popular support for social exclusion, curtailing the rights of individuals labeled as "crazy," starting with their right to be included in society. To answer this question, we present in this article an explanatory model for the social exclusion of individuals suffering from mental disorders, evaluating how beliefs about the nature of mental disorders, prejudice, and threat perception relate to the social exclusion of these individuals.

Beliefs about the nature of social groups are at the root of prejudice and discrimination against these groups (C. R. Pereira, Torres, Falcão, \& Pereira, 2013; Read, Haslam, Sayce, \& Davies, 2006). According to Lacerda et al. (2002) and A. Pereira, C. R. Pereira and Monteiro (2016), analysis of these beliefs is crucial because representations concerning the nature of social groups act as organizing principles that promote the expression of prejudice and discrimination. The impact of subscribing to these beliefs on attitudes towards mental disorders is the most important; in this regard, Pescosolido et al. (2010) and Schlier, Schmick and Lincoln (2014) investigate the relationship between beliefs about mental disorders and social distance from people suffering from mental disorders and observe that the causal beliefs are related to greater social distance from people with serious mental disorders. However, these findings show great variations and inconsistency across studies (Read et al., 2006; Schlier et al., 2014), which highlights the need to situate the analysis of the impact of these beliefs in a general framework of factors that promote the social exclusion of people suffering from mental disorders, such as prejudice and perceptions of threat.

Prejudice and the stigmatization of mental disorders have extremely negative consequences for this group. In a general sense, individuals have a greater tendency to disapprove people suffering from mental disorders compared to people with a physical illness, in addition to attributing more responsibility to them for their condition (Rusch, Angermeyer, \& Corrigan, 2005).

Currently, the discourse on the subject of mental disorders has been based on the psychosocial paradigm, which recommends guaranteeing the human rights and social inclusion of individuals suffering from mental disorders (Costa-Rosa, 2012; Mfoafo-M'Carthy \& Huls, 2014); these are values that form the basis of the Brazilian psychiatric reform. Under pressure from anti-discriminatory laws and the principles of equality and liberty advocated by liberal democracies and attempting to show that they are socially and politically correct, people have begun to act in such a manner that would be viewed as just and legitimate (C. Pereira, Vala \& Leyens, 2009). According to C. Pereira, Vala, and Costa-Lopes (2010), in contexts where there is pressure from legislation or social norms against prejudice, exclusion occurs only when individuals can justify their actions by appealing to non-discriminatory criteria (C.R. Pereira \& Souza, 2016).

The Model of Justified Discrimination - MJD (C. Pereira et al., 2009, 2010) proposes that the relationship between prejudice and discrimination/exclusion is mediated by factors that justify discrimination. Threat perception acts 
Maciel, S. C., Pereira, C. R., Lima, T. J. S., Souza, L. E. C., Camino, L., \& Silva, G. L. S. (2019). Social Exclusion of People.

as a justification in that it does not directly evoke the idea of social hierarchy among groups (which would be perceived as an illegitimate argument for discrimination) but can be perceived as a natural reaction in defence of the interests and survival of the ingroup (perceived as a legitimate argument for discrimination/exclusion). In the context of prejudice against people suffering from mental disorders, we propose that perception of threat (Rusch et al., 2005) acts as a justification for prejudice in that it can be viewed not as a discriminatory justification but instead as a natural reaction in defence of society's well-being.

Based on this review, this study aims to propose an explanatory model for the social exclusion of individuals suffering from mental disorders, based on beliefs about the nature of mental disorders, prejudice, and threat perception. We propose that beliefs about mental disorders will be at the root of prejudice against people suffering from mental disorders and that this prejudice accounts for individuals' support for the social exclusion of mental disorders. The explanatory model we propose follows the MJD in predicting that individuals use the perception that people suffering from mental disorders represent a threat as a factor to legitimate discriminatory behaviors against this group (C. Pereira et al., 2010). We analyse to what extent prejudice motivates the use of threat perception as a basis for the support that people give to the social exclusion of people suffering from mental disorders. Thus, threat perception should mediate the relationship between prejudice and social exclusion since it functions as a justifying factor in the social exclusion of these individuals. To that end, two studies were conducted. Study 1 aims to test an explanatory model for the support that people give to the social exclusion of people suffering from mental disorders, and Study 2 aims to replicate this model and go further, testing the hypothesis that threat perception acts as a justification for prejudice against this group.

\section{Study 1}

In this study, we argue that beliefs about the origin of mental disorders are the basis for prejudice against this social group (Hypothesis 1), i.e. people use them as the basis for their attitudes and behavior towards people suffering from mental disorders (Oliveira, Lima, Silva, Oliveira \& Alves, 2011; Read et al., 2006). However, the findings reported in the literature on the relationship between beliefs and prejudice regarding mental disorder have been varied and inconsistent, making it difficult to formulate a more direct hypothesis concerning which beliefs form the basis of prejudice against these individuals (Schlier et al., 2014). It is expected that prejudice will predict the perception that the people suffering from mental disorders represent a threat (Hypothesis 2), which in turn will predict their exclusion (Hypothesis 3). Specifically, the greater the degree of prejudice, the more an individual will perceive this social group as a threat; and the greater this perception of threat, the greater will be an individual's support for their exclusion of the social group.

\section{Method}

\section{Participants}

The participants consisted of a convenience sample of 254 university students, from public and private universities, with a mean age of 24.91 (standard deviation [SD] $=7.92$ ). The majority were female (74\%), being distributed equally among the Nursing, Medicine, Psychology, and Social Services programs. We chose a college sample because we believe that attitudes are strong predictors of future behavior (Homer \& Kahle, 1988). Thus, this study helps in identifying the attitudes of future professionals in mental health early. With regard to their experience with mental disorders, $20.5 \%$ declared having a member of their family suffering from a mental disorder. In order to ensure that the participants already had contact with mental health issues, the sample inclusion criterion used for the study were students from the third period of their respective courses.

\section{Instruments}

Participants responded a questionnaire containing four scales developed or adapted by the authors of this study. They are summarily described below.

Beliefs about Mental Disorders Scale (BAMDS). This scale was constructed and validated by Maciel et al. (2015) to evaluate six types of beliefs about the nature of mental disorders: psychological, religious, biological, drug use, socioeconomic, and contingent. The instrument is composed of 30 items that participants would answer on a 5-point scale ranging from "totally agree" (1) to "totally disagree" (5). The following indices of internal consistency (Cronbach's alpha, $\alpha)$ were adequate: psychological $(\alpha=.75)$; religious $(\alpha=$ $.84)$; biological $(\alpha=.72)$; drug use $(\alpha=.81)$; socioeconomic $(\alpha=.79)$, and contingent $(\alpha=.80)$.

Prejudice Against Mental Disorders Scale. This instrument was adapted by the authors to measure prejudice towards people suffering from mental disorders, based on the scale developed by Pettigrew and Meertens (1995) to measure blatant prejudice. It consists of nine items that describe everyday situations related to the rejection of closeness, responded using a scale ranging from "not at all uncomfortable" (1) to "very uncomfortable" (5). The results of a factorial analysis using principal axes showed a factor that explained $45.54 \%$ of the variance, with factor loadings varying from 0.58 to 0.78 . The internal consistency of this factor was adequate $(\alpha=.84)$.

Threat Perception regarding Mental Disorder Scale. This scale measures threat perception regarding people suffering from mental disorders. It consists of nine items that the participant responds to using a scale ranging from "totally agree" (1) to "totally disagree" (5). The results of a factorial analysis using the principal axes method showed that two factors explained $57.7 \%$ of the total variance. The factor loadings varied between .79 and .66 for the first factor $(\alpha=.81)$ and between .79 and .57 for the second factor $(\alpha=.74)$. This scale yielded an internal consistency index 
of .85 , which is sufficient to calculate a general indicator of the perceived threat.

Social Exclusion Scale. This scale measures the level of a participant's agreement with statements about the manner in which people suffering from mental disorder are treated in the community or in psychiatric hospitals. The questionnaire consists of six items that the participant responds to using a scale ranging from "totally disagree" (1) to "totally agree" (5). The results of a factorial analysis using the principal axes method showed a factor that explained $43.37 \%$ of the total variance. The factor loadings varied from .77 to .56 . Alpha coefficient is sufficient to calculate an indicator for social exclusion $(\alpha=.73)$, in which higher scores indicate greater support for confining people suffering from mental disorders to psychiatric hospitals.

\section{Procedure}

Data collection. Collaborators, instructed not to interfere in participants' responses, conducted the data collection. All subjects were informed of the voluntary nature of their participation in the research, the guarantee of anonymity of the given answers and respect to the ethical guidelines that govern research with human beings. Data were collected from willing participants after they had signed a free informed consent form.

Data analysis. The data were organized in tables and analysed using SPSS version 21.0. For the analysis of the scales, in addition to descriptive statistical procedures to describe the sample (mean, standard deviation, etc.), factor analysis was performed to verify the factorial validity of the measures. Internal consistency was also verified using Cronbach's alpha. Hierarchical regression analysis was subsequently conducted with the intention of proposing an explanatory model for the exclusion of people suffering from mental disorders that takes into account beliefs about the origins of mental disorders, prejudice, and threat perception regarding this social group.

\section{Ethical Considerations}

This research project was duly approved by the Research Ethics Committee of the Centre for Health Sciences of the Federal University of Paraíba - CEP/CCS, under Protocol n. $0348 / 12$.

\section{Results}

We began with a regression model that assessed the effect of beliefs about mental disorders (psychological, religious, biological, drug use related, socioeconomic, and contingent) on prejudice against mental disorders. In this regression equation, the multiple regression coefficient was marginally significant, $R^{2}=.05, F(6,247)=1.94, p=.075$. Only the effect of religious belief was positive and significant, with greater adherence to this belief implying greater prejudice against people suffering from mental disorders.
In the second analysis, regression analysis was performed on threat perception in beliefs about mental disorders and in prejudice; the regression coefficient was significant, $R^{2}=.41, F(7,246)=24.5, p<.001$. The results indicate that threat perception is directly explained by religious and contingent beliefs (greater adherence to these beliefs implies a greater perception of threat) and by prejudice (with a higher level of prejudice implying a greater perception of threat). Biological belief negatively predicts threat perception, i.e., a person with greater belief in the biological causes of mental disorders was less likely to perceive the people suffering from mental disorders as a threat. In the third equation, social exclusion was subjected to regression analysis with respect to beliefs, prejudice, and threat perception. The regression coefficient was significant, $R^{2}=.32, F(8,245)=14.41 p<.001$, with contingent beliefs, prejudice, and threat perception implying greater support for social exclusion, with greater agreement with these variables being related to greater exclusion of people suffering from mental disorders. The results of the regressions are summarized in Table 1.

Table 1

Regression Coefficients for the Models Tested

\begin{tabular}{|c|c|c|c|c|c|c|}
\hline & \multicolumn{2}{|c|}{ Prejudice } & \multicolumn{2}{|c|}{$\begin{array}{c}\text { Threat } \\
\text { Perception }\end{array}$} & \multicolumn{2}{|c|}{ Exclusion } \\
\hline & B & $\beta$ & B & $\beta$ & B & $\beta$ \\
\hline Constant & 2.26 & & 1.57 & & 1.04 & \\
\hline Psychological & 0.01 & .01 & 0.03 & .03 & -0.09 & -.10 \\
\hline Socioeconomic & 0.08 & .08 & -0.10 & -.11 & -0.01 & -.01 \\
\hline Biological & -0.02 & -.02 & -0.24 & $-.23^{* *}$ & -0.00 & -.00 \\
\hline Religious & 0.20 & $.20^{* *}$ & 0.17 & $.19^{* *}$ & 0.06 & .07 \\
\hline Drugs & -0.06 & -.05 & 0.08 & .08 & -0.06 & -.06 \\
\hline Contingent & -0.07 & -.08 & 0.09 & $.12 *$ & 0.16 & $.22^{* *}$ \\
\hline Prejudice & & & 0.44 & $.50^{* *}$ & 0.14 & $.17^{*}$ \\
\hline $\begin{array}{l}\text { Threat } \\
\text { Perception }\end{array}$ & & & & & 0.35 & $.38^{* *}$ \\
\hline$R^{2}$ & & & & & & \\
\hline
\end{tabular}

Figure 1(a) shows a synthesis of the variables with significant regression weights that comprise the explanatory model of exclusion of people suffering from mental disorders proposed in this study. In this model, religious belief about the origin of mental disorders implies greater prejudice and greater threat perception, and belief in the contingent nature of mental disorders is related to greater threat perception and greater support for social exclusion. Conversely, a belief in the biological nature of mental disorders predicts less threat perception. Equally important is the fact that prejudice implies greater threat perception, which is the main direct source of support for the exclusion of people with psychological distress. 
(a)

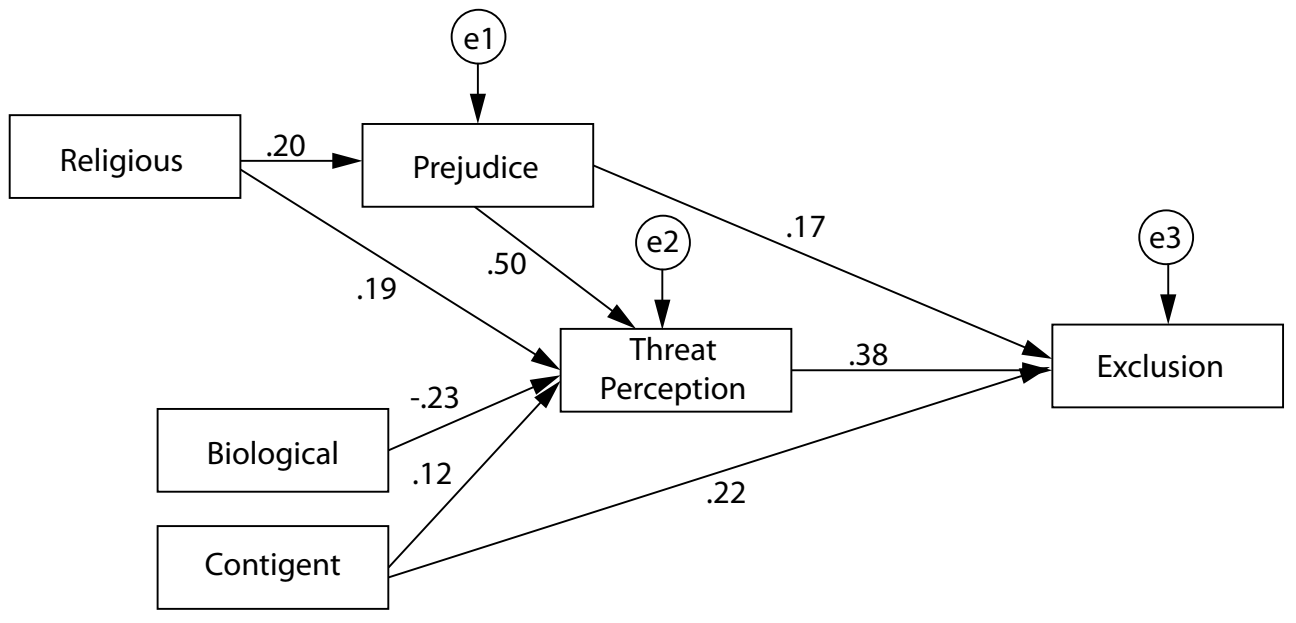

(b)

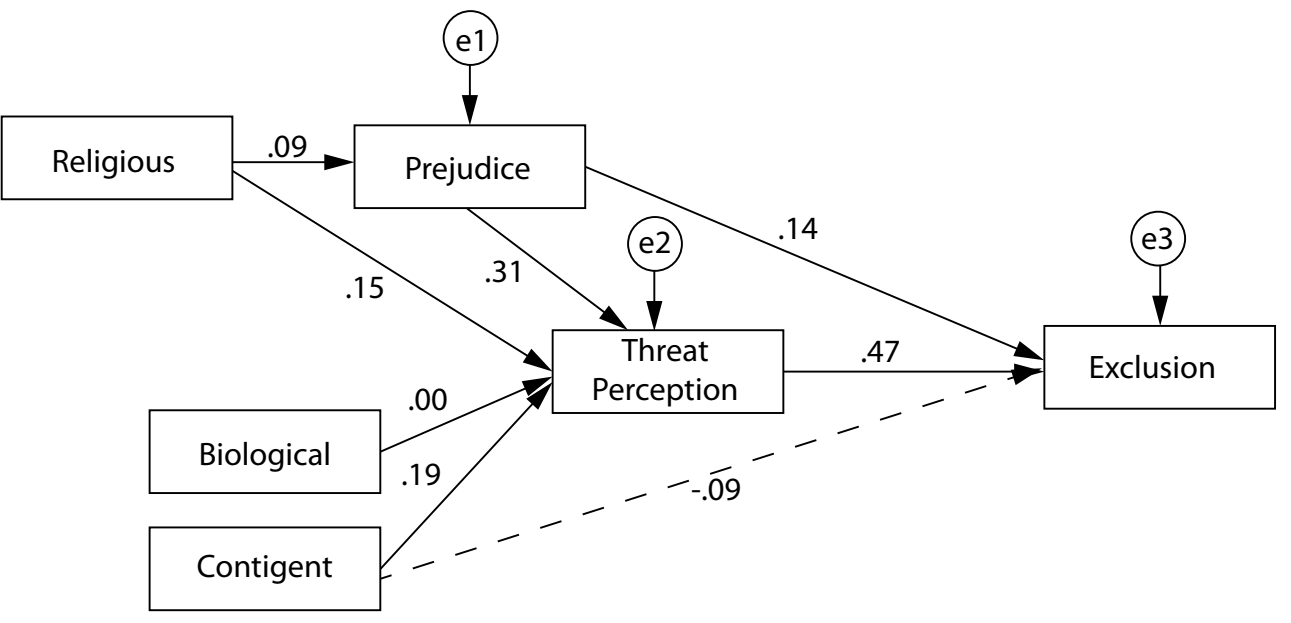

Figure 1. Explanatory model for the exclusion of people suffering from mental disorders: (a) Study 1 and (b) Study 2.

\section{Discussion}

The results indicate that beliefs, prejudice, and threat perception are related to the social support for the exclusion of individuals suffering from mental disorders. As proposed, beliefs form the basis for prejudice and threat perception with respect to mental disorders, confirming Hypothesis 1. Indeed, some studies have shown that information about the origin of mental disorders is associated with positive or negative attitudes towards people with mental disorders, depending on the belief in question (Haslam, 2011; Peluso \& Blay, 2011; Read et al., 2006). As noted above, belief in the biological nature of mental disorders led to a lower perception of threat. This result is in line with some approaches that aim to reduce the stigma of mental disorders by emphasizing its biological and genetic causes, i.e., characterizing mental disorders as a disease like any other (Phelan, 2002), in which individuals have no responsibility for their illness.

By contrast, religious belief about the origin of mental disorders is related to greater prejudice and threat perception, whereas contingent belief is related to greater threat perception and exclusion. Some studies have indicated that belief in religious causes of mental disorders is negatively associated with representations and attitudes towards people suffering from mental disorders (Borras et al., 2007). Such causal beliefs focus on explanatory aspects of health and mental illness that were very common in the Middle Ages, when these symptoms were considered abnormal behaviors caused by religious factors, such as demonic motivations, leading to the "witchhunt" of the Roman Catholic Inquisition. It is possible that belief in contingent factors related to external factors such as a blow to the head (Furnham \& Telford, 2011) leads individuals to believe that recovery is less likely, that the subject is to blame, and that there may be serious brain disorders, which is why it is related to threat perception and exclusion. Finally, prejudice predicts the perception that a person with mental disorders poses a threat, confirming Hypothesis 2, and the perception of threat predicts exclusion, as proposed by Hypothesis 3 . These results corroborate our suggestion that prejudice against mental disorders is related to threat perception, as proposed by the MJD (C. Pereira et al., 2010), and that a greater perception of threat leads to the exclusion of mental disorders.

In the second study, we aim to replicate this proposed model, analyzing its ability to explain the relationship 
between prejudice and support for the social exclusion of people suffering from mental disorders.

\section{Study 2}

Study 2 tests whether the model proposed in the previous study can be replicated with another sample, also testing the additional hypothesis that threat perception acts as a justification for prejudice in that it avoids directly evoking the idea of social hierarchy, which however may instead be viewed as a natural reaction of self-defence (C. Pereira et al., 2010). Thus, we evaluate whether prejudice predicts the exclusion of individuals with mental disorders, with this relationship being mediated by threat perception (Hypothesis 4).

\section{Method}

\section{Participants}

This study followed the same sampling criteria as Study 1. Hence, participants consisted of a convenience sample of 236 university students from the third period of Psychology, Nursing, Physical Therapy, and Nutrition in public and private universities. The majority were female $(79.6 \%)$, being distributed among the Psychology (54.4\%), Nursing (30.1\%), Physical Therapy (10.6\%), and Nutrition (5.9\%) programs, with a mean age of $25.91(\mathrm{SD}=7.7)$. With regard to their experience with mental disorders, $21.6 \%$ declared they had a family member with mental disorders.

\section{Instruments}

The same instruments used in the previous study were employed.

\section{Procedure}

Data collection. The same procedure used in data collection for Study 1 was employed.

Data analysis. The data were organized in tables and analyzed using SPSS version 21.0 and AMOS version 20 . A path analysis was conducted based on the variancecovariance matrix and adopting the Maximal Likelihood (ML) estimator. Cases of missing data constituted less than $0.5 \%$ of observations and were therefore excluded from the analyses. To assess the goodness of fit of the proposed model, the following indicators were used: chi-square to degrees of freedom ratio $\left(\chi^{2} / \mathrm{df}\right)$, where values lower than 5 indicate an adequate model fit; the goodness-of-fit index (GFI) and the comparative fit index (CFI), for which values of 0.90 or greater indicate good fit; and the root mean square error of approximation (RMSEA), in which values of 0.06 or lower indicate satisfactory fit and values up to 0.10 are still considered acceptable (Garson, 2012). Mediation analysis was also conducted using AMOS, with 1,000 bootstrapping samples, and the confidence intervals of the indirect effects were calculated using the bias corrected (BC) method with a $90 \%$ confidence interval $(\mathrm{CI})$.

\section{Results}

Path analysis was conducted to evaluate whether the model proposed in the preceding study could be replicated. The model obtained the following fit indexes: $\chi^{2}(7)=31.8, p$ $<.001, \chi^{2} / \mathrm{df}=4.55, G F I=.96, C F I=.82, R M S E A=0.123$, $90 \%$ CI [0.082, 0.168]. As can be seen in Figure 1(b), the regression weights of religious belief with prejudice, of biological belief with threat perception, and of contingent belief with exclusion were not significant (the dotted lines indicating non-significant regression weights). The remaining regression weights were significantly different from zero $(\lambda \neq$ $0 ; z>1.96, p<.05)$. Next, the role of threat perception as a mediator between prejudice and the exclusion of people with mental disorders was tested. The total standardized effect of prejudice on exclusion was .28 , with the direct effect being .14 and the indirect effect mediated by threat perception being .14. The indirect effect is reliable, given that the $\mathrm{CI}$ calculated does not include the value of zero, $90 \% C I[0.08,0.18]$. Both direct and indirect effects were significant, $p<.01$.

\section{Discussion}

The results of this study support Hypotheses 2 and 3 as proposed in the previous study, although they do not completely replicate the model proposed in Study 1. Beliefs do not significantly predict prejudice against people suffering from mental disorders; thus, Hypothesis 1 is not corroborated, although religious belief predicts threat perception, as in Study 1 . One possible explanation for this difference is that the composition of the sample may have influenced the effect of beliefs on prejudice: the majority of the sample (53.4\%) in Study 2 was composed of psychology students, who tend to agree more with psychosocial explanations of mental disorders (Lacerda et al., 2002), whereas the previous study sample was evenly distributed among students from various study programs. It is possible that beliefs about the nature of mental disorders vary among different social groups, whether they are composed of lay people, people from different professions, or people who have contact with mental disorders (Furnham $\&$ Telford, 2011). The results reported in the literature are varied and inconsistent with regard to the beliefs that underlie prejudice against people suffering from mental disorders (Schlier et al., 2014), and these inconsistencies can be partially explained by the different samples used in these studies.

In turn, prejudice significantly predicted threat perception, with greater prejudice being related to greater threat perception, which corroborates Hypothesis 2. Threat perception also significantly predicts exclusion, with higher perceptions of threat being related to greater exclusion of people suffering from mental disorders, which supports Hypothesis 3. Moreover, threat perception acts as a mediator between prejudice and the 
Maciel, S. C., Pereira, C. R., Lima, T. J. S., Souza, L. E. C., Camino, L., \& Silva, G. L. S. (2019). Social Exclusion of People.

exclusion of people with psychological distress, confirming Hypothesis 4. These results agree with those suggested by the MJD (C. Pereira et al., 2010). Threat perception mediates the effect of prejudice because it serves as a justification for exclusion, since it can be perceived as a natural defensive reaction (C.R. Pereira \& Souza, 2016) against the danger allegedly posed by people suffering from mental disorders.

\section{General Discussion}

In two studies, we analyzed the role played by beliefs about the nature of mental disorders, prejudice, and the perception of threat in people's degree of support for the social exclusion of individuals suffering from mental disorders. The results of Study 1 provided evidence in support of Hypothesis 1, confirming that beliefs about the origin of mental disorders are at the root of prejudice against individuals with mental disorders. We noted that beliefs of a religious nature that attribute mental disorders to the action of external entities such as demons, spirits, deities or to God's will (Borras et al., 2007) are directly related to prejudice against people suffering from mental disorders. However, these results were not replicated in Study 2. Beliefs also predicted threat perception. Belief in the biological nature of mental disorders was associated with lower threat perception, whereas religious belief predicted higher threat perception.

These results are consistent with the idea that the theories that individuals elaborate about the nature of social groups are important for understanding intergroup tensions because they act as organizing principles that promote the expression of prejudice and discrimination (C.R. Pereira et al., 2013). Moreover, when individuals use beliefs to describe the nature of social groups, they do so primarily to justify social inequality and discrimination against minority groups (Lacerda et al., 2002). Consistent with our findings that beliefs in genetic causes are less related to prejudice, some studies have shown that it is possible to reduce the stigma of people suffering from mental disorders by emphasizing its biological and genetic causes, characterizing mental disorders as a disease like any other (Phelan, 2002). By contrast, it is possible that beliefs in religious and contingent factors as the cause of mental disorders may lead to perceiving a person with mental disorders as someone who is not in control of him- or herself, contributing to greater threat perception.

However, the results observed in Studies 1 and 2 with regard to beliefs differed, reflecting the great variability and inconsistency observed in the literature on the relationship between beliefs and stigmas related to mental disorders (Read et al., 2006). As stated above, it is possible that beliefs about the nature of mental disorders vary among different social groups, for example, between laypersons and professionals from different areas of the health profession (Furnham \& Telford, 2011), or due to personal characteristics such as contact with someone who has mental disorders (Lee et al., 2014). In the present research, this variability may have resulted from different levels of student involvement in their courses, in addition to their contact with people with mental disorders or with relatives of these people.

The results also corroborate Hypotheses 2 and 3. Prejudice predicts threat perception, and threat perception predicts social exclusion. Prejudice against people suffering from mental disorders is related to, among other things, a perception of these people as someone dangerous who should be kept away from society (Rusch et al., 2005), which also goes back to what occurred in the Middle Ages as it had been analyzed in Foucault's studies on the history of madness. It is a disturbing finding in a context of Psychiatric Reform that promotes social inclusion and discourages any form of stigmatizing representations and social exclusion of people suffering from mental disorders. Some studies have also demonstrated that a perception of threat leads to shunning and avoiding social contact with this social group (Angermeyer, Buyantugs, Kenzine \& Matschinger, 2004). Thus, in spite of the efforts promoted by the psychiatric reform, one can still perceive the difficulty of society in dealing with the phenomenon of madness, maintaining beliefs about religious causes that legitimize prejudice and social exclusion of individuals with mental disorders.

Finally, the results also corroborate Hypothesis 4, confirming that threat perception functions as a mediator between prejudice and the exclusion of people suffering from mental disorders. In this sense, threat perception can function as a "non-discriminatory" justification for the social exclusion of these individuals, since it can be understood as a natural reaction of self-defence that is perceived as legitimate grounds for discrimination, as proposed by the model of justified discrimination (C. Pereira et al., 2010).

These results show that the social exclusion of people suffering from mental disorders can be understood in part by beliefs about the nature of mental disorders, prejudice and threat perception. Although in the context of the psychiatric reform there are institutional mechanisms that provide for the social inclusion of people suffering from mental disorders, it is also necessary to transform the relationship of Western society with these individuals, which has been crystallized in years of social exclusion and institutionalization that sustain negative attitudes and the perception that these individuals pose a threat to society (Foucault, 1960/2012). Such representations are the basis for socially excluding and restricting the rights of individuals portrayed as "crazy," fostering discriminatory attitudes and opposition to inclusive policies, as exemplified by the resistance to the implementation of a broad-based psychiatric reform (Mfoafo-M'Carthy \& Huls, 2014).

It is even possible that psychiatric wards may eventually be emptied and abolished, without this action necessarily signifying a change in how society addresses mental disorders. When we fight for the inclusion of people who suffer from mental disorders in our society, we fight for changes in how people relate to each other, for a new way of living together that restructures broader social-familial relationships. It is not enough to simply create new therapeutic areas dressed up in new clothes; what is needed is a change in beliefs and attitudes towards mental disorders. According to Barros (2000), it is necessary to deconstruct 
not only the physical structures of psychiatric wards but also the ideas, notions, and prejudices that accompany and shape them and that are part of the social imaginary. In this research carried out on samples of university students, the presence of prejudice, threat perceptions and support for social exclusion is especially worrying since the participants will become professionals whose practices may be influenced by their prejudice and discriminatory attitudes. Moreover, the opinions of professionals trained in universities are socially valuable in that they are perceived as scientifically based. In this way, the beliefs they hold about the nature of mental illness can reinforce stereotypes and prejudices that reproduce the status quo in an increasingly unequal and excluding society.

Given this context, this study contributes to understanding the factors related to stigmatization and discrimination against people with mental disorders. Understanding the beliefs that underlie discriminatory attitudes towards these individuals can contribute to planning social interventions that seek to modify or clarify the nature of mental disorders.

Our results showed that causal beliefs about mental disorders are related to prejudice and social exclusion, and therefore changing the perception of people suffering with mental disorders as a threat is also an important element in enabling the social inclusion of people with mental disorders. Although their image as threatening or dangerous is one of the central features of stereotypes regarding mental disorders (Corrigan et al., 2012), people with mental disorders are far from posing an ongoing and real threat to society (Furnham $\&$ Telford, 2011; Rusch et al., 2005). In this sense, promoting changes in popular attitudes are as important as institutional changes, using an educational strategy to clarify these and other misconceptions about mental disorders can contribute to their greater social inclusion. Furthermore, the findings obtained in these studies with a sample of academics from health courses points to the need to question the role of curriculum guidelines regarding mental health (Carneiro \& Porto, 2014). Changes in the assistance and training model will be necessary, allowing the deconstruction of the conception of madness rooted in society, which complicates the process of social reintegration of people suffering from mental disorders and therefore the establishment of the psychiatric reform.

Although these findings contribute to an understanding of the social exclusion of people suffering from mental disorders, it is possible to specify limitations in the conducted studies, noting that these studies were performed with specific samples of university students, albeit from different professions in the fields of health and social work. It is possible that the results observed in a sample from the general population would be more complex and enlightening, given that university students are in closer contact with scientific views of mental disorders. Moreover, the current research took into account only the contact of the participants with family members suffering from mental disorders, but not the contact resulting from their university education at different moments of the course. This possibility of contact raises new research questions to be answered in future studies that can test the hypotheses proposed here, considering the influence of the contact that is promoted by the practical activities that students have to be involved with during their university education.

Another limitation is the correlational nature of the study, which does not allow the presence of causal relationships to be confirmed or ensure the direction of the effects between variables, even though the results supported the proposed model. New studies using experimental settings or longitudinal designs in which different beliefs about the nature of mental disorders are highlighted and their impact on prejudice and exclusion are observed could more precisely identify the reliability of the direction of these proposed relationships. Nevertheless, the direction of the relationships proposed is theoretically consistent with the idea that beliefs are the basis for prejudice, which is mediated by threat perception (C. Pereira et al., 2010).

Finally, although we can note that threat perception can be used to justify discrimination against people suffering from mental disorders, our studies do not directly test whether threat perception is perceived as a non-discriminatory justification. Future research may directly evaluate this issue by means of a study that manipulates the type of justification used to legitimize an act of discrimination, comparing a scenario in which a threat is noted as justification to a scenario in which no threat is noted as justification. Importantly, the results obtained here can support intervention projects that mainly focus on education, discussion and debate that aims to change beliefs to reduce prejudice and promote social inclusion, using the university as a privileged context for the production of theoretical-practical knowledge that is essential for the qualified education of professionals in the mental health network.

\section{References}

Alverga, A., \& Dimenstein, M. (2006). A reforma psiquiátrica e os desafios na desinstitucionalização da loucura [Psychiatric reform and the challenges in deinstitutionalization of madness]. Interface, Comunicação, Saúde, Educação, 10(20),299-316. doi:10.1590/S1414-32832006000200003

Angermeyer, M. C., Buyantugs, L., Kenzine, D. V., \& Matschinger, H. (2004). Effects of labelling on public attitudes towards people with schizophrenia: Are there cultural differences? Acta Psychiatrica Scandinavica, 109(6), 420-425. doi:10.1111/j.1600-0047.2004.00310.x

Arvaniti, A., Samakouri, M., Kalamara, E., Bochtsou, V., Bikos, C., \& Livaditis, M. (2009). Health service staff's attitudes towards patients with mental illness. Social Psychiatry and Psychiatric Epidemiology, 44(8), 658665. doi:10.1007/s00127-008-0481-3

Barros, S. (2000). Ensino da enfermagem psiquiátrica e reabilitação psicossocial [Psychiatric nursing education and psychosocial rehabilitation]. In M. S. B. Jorge, W. V. Silva, \& F. B. Oliveira (Orgs.), Saúde mental: Da prática psiquiátrica asilar ao terceiro milênio [Mental health: From asilar psychiatric practice to the third millennium] (pp. 73-80). São Paulo, SP: Lemos. 
Maciel, S. C., Pereira, C. R., Lima, T. J. S., Souza, L. E. C., Camino, L., \& Silva, G. L. S. (2019). Social Exclusion of People.

Borras, L., Mohr, S., Brandt, P., Gilliéron, C., Eytan, A., \& Huguelet, P. (2007). Religious beliefs in schizophrenia: Their relevance for adherence to treatment. Schizophrenia Bulletin, 33(5), 1238-1246. doi:10.1093/ schbul/sbl070

Carneiro, L. A., \& Porto, C. C. (2014). Saúde mental nos cursos de graduação: Interfaces com as diretrizes curriculares nacionais e a reforma psiquiátrica [Mental health in undergraduate courses: Its interface with national curriculum guidelines and with the psychiatric reform]. Cadernos Brasileiros de Saúde Mental, 6(14), 150-167. Retrieved from http://incubadora.periodicos. ufsc.br/index.php/cbsm/article/view/1666/3944_

Corrigan, P. W., Morris, S. B., Michaels, P. J., Rafacz, J. D., \& Rusch, N. (2012). Challenging the public stigma of mental illness: A meta-analysis of outcome studies. Psychiatric Services, 63(10), 963-973. doi:10.1176/appi. ps.201100529

Costa-Rosa, A. (2012). O modo psicossocial: Um paradigma das práticas substitutivas ao modo asilar [Psychosocial way: A paradigm of substitutive practices to asylum model]. In P. Amarante (Org.), Ensaios: Subjetividade, saúde mental e sociedade [Tests: Subjectivity, mental health and society] (pp. 141-168). Rio de Janeiro, RJ: FIOCRUZ.

Evans-Lacko, S., Henderson, C., \& Thornicroft, G. (2013). Public knowledge, attitudes and behavior regarding people with mental illness in England 2009-2012. The British Journal of Psychiatry Supplement, 202(s55), 5157. doi:10.1192/bjp.bp.112.112979

Foucault, M. (2012). História da loucura na Idade Clássica [History of madness in the classical age] (J. T. Coelho Neto, Trans., 9th ed.). São Paulo, SP: Perspectiva. (Original work published 1960).

Furnham, A., \& Telford, K. (2011). Public attitudes, lay theories and mental health literacy: The understanding of mental health. In L. L'Abate (Ed.), Mental illnesses: Understanding, prediction and control (pp. 3-22). Rijeka, Croatia: InTech.

Garson, G. D. (2012). Structural equation modeling. Asheboro, NC: Statistical Publishing Associates.

Haslam, N. (2011). Genetic essentialism, neuroessentialism, and stigma. Psychological Bulletin, 137(5), 819-824. doi:10.1037/a0022386

Homer, P. M., \& Kahle, L. R. (1988). A structural equation test of the value-attitude-behavior hierarchy. Journal of Personality and Social Psychology, 54(4), 638-646. doi:10.1037/0022-3514.54.4.638

Jodelet, D. (2005). Loucuras e representações sociais [Madness and social representations] (L. Magalhães, Trans.). Petrópolis, RJ: Vozes.
Lacerda, M., Pereira, C., \& Camino, L. (2002). Um estudo sobre as formas de preconceito contra homossexuais na perspectiva das representações sociais [A study of prejudice forms against homosexuals anchored on social representations]. Psicologia: Reflexão e Crítica, 15(1), 165-178. doi:10.1590/S0102-79722002000100018

Lee, A. A., Laurent, S. M., Wykes, T. L., Andren, K. A. K., Bourassa, K. A., \& Mckibbin, C. L. (2014). Genetic attributions and mental illness diagnosis: Effects on perceptions of danger, social distance, and real helping decisions. Social Psychiatry and Psychiatric Epidemiology, 49(5), 781-789. doi:10.1007/s00127-013-0764-1

Maciel, S. C., Barros, D. R., Camino, L. F., \& Melo, J. R. F. (2011). Representações sociais de familiares acerca da loucura e do hospital psiquiátrico [Social representations of familiar members concerning madness and the psychiatric hospital]. Temas em Psicologia, 19(1), 193-204. Retrieved from http://pepsic.bvsalud. org/scielo.php?script=sci_arttext\&pid $=$ S 1413 389X2011000100015

Maciel, S. C., Pereira, C. R., Lima, T. J. S., \& Souza, L. E. C. (2015). Desenvolvimento e validação da escala de crenças sobre a doença mental [Development and validation of the beliefs about mental illness scale]. Psicologia: Reflexão e Crítica, 28(3), 463-473. doi:10.1590/1678-7153.201528305

Mfoafo-M'Carthy, M., \& Huls, S. (2014). Human rights violations and mental illness: Implications for engagement and adherence. SAGE Open, 4, 1-18. doi: $10.1177 / 2158244014526209$

Nee, C., \& Witt, C. (2013). Public perceptions of risk in criminality: The effects of mental illness and social disadvantage. Psychiatry Research, 209(3), 675-683. doi:10.1016/j.psychres.2013.02.013

Oliveira, R. M., Lima, A. E. S., Silva, D. G., Oliveira, M. D. F., \& Alves, K. S. M. (2011). Visão dos acadêmicos de enfermagem em relação ao cliente portador de transtorno mental [View of nursing students in relation to mental disorder customer]. Cadernos de Ciência e Saúde, 1(2), 75-85.

Peluso, E. T. P., \& Blay, S. L. (2011). Public stigma and schizophrenia in São Paulo city. Revista Brasileira de Psiquiatria, 33(2), 130-136. doi:10.1590/S151644462010005000004

Pereira, A., Pereira, C. R., \& Monteiro, M. B. (2016). Normative pressure to reduce prejudice against homosexuals: The buffering role of beliefs about the nature of homosexuality. Personality and Individual Differences, 96, 88-99. doi:10.1016/j.paid.2016.02.042

Pereira, C., Vala, J., \& Costa-Lopes, R. (2010). From prejudice to discrimination: The legitimizing role of perceived threat in discrimination against immigrants. European Journal of Social Psychology, 40(7), 12311250. doi:10.1002/ejsp.718 
Pereira, C., Vala, J., \& Leyens, J. P. (2009). From infrahumanization to discrimination: The mediation of symbolic threat needs egalitarian norms. Journal of Experimental Social Psychology, 45(2), 336-344. doi:10.1016/j.jesp.2008.10.010

Pereira, C. R., \& Souza, L. E. C. (2016). Fatores legitimadores da discriminação: Uma revisão teórica [Legitimizing factors of discrimination: A theoretical review]. Psicologia: Teoria e Pesquisa, 32(2), e322222. doi:10.1590/0102-3772e322222

Pereira, C. R., Torres, A. R. R., Falcão, L., \& Pereira, A. S. (2013). O papel de representações sociais sobre a natureza da homossexualidade na oposição ao casamento civil e à adoção por famílias homoafetivas [The role of social representations about the nature of homosexuality: Opposition to civil marriage and adoption by homoaffective families]. Psicologia: Teoria e Pesquisa, 29(1), 79-89. doi:10.1590/S0102-37722013000100010

Pescosolido, B. A. (2013). The public stigma of mental illness: What do we think; what do we know; what can we prove? Journal of Health and Social Behavior, 54(1), 1-21. doi:10.1177/0022146512471197

Pescosolido, B. A., Martin, J. K., Long, J. S., Medina, T. R., Phelan, J. C., \& Link, B. G. (2010). "A disease like any other"? A decade of change in public reactions to schizophrenia, depression, and alcohol dependence. American Journal of Psychiatry, 167(11), 1321-1330. doi:10.1176/appi.ajp.2010.09121743

Pescosolido, B. A., Medina, T. R., Martin, J. K., \& Long, K. S. (2013). The "backbone" of stigma: Identifying the global core of public prejudice associated with mental illness. American Journal of Public Health, 103(5), 853860. doi:10.2105/AJPH.2012.301147

Pettigrew, T. F., \& Meertens, R. W. (1995). Subtle and blatant prejudice in Western Europe. European Journal of Social Psychology, 25(1), 57-75. doi:10.1002/ejsp.2420250106

Phelan, J. C. (2002). Genetic bases of mental illness - a cure for stigma? Trends in Neurosciences, 25(8), 430-431. doi:10.1016/S0166-2236(02)02209-9

Read, J., Haslam, N., Sayce, L., \& Davies, E. (2006). Prejudice and schizophrenia:Areview of the "mental illness is an illness like any other" approach. Acta Psychiatrica Scandinavica, 114(5), 303-318. doi:10.1111/j.1600-0447.2006.00824.x

Rusch, N., Angermeyer, M. C., \& Corrigan, P. W. (2005). Mental illness stigma: Concepts, consequences, and initiatives to reduce stigma. European Psychiatry, 20(8), 529-539. doi:10.1016/j.eurpsy.2005.04.004

Schlier, B., Schmick, S., \& Lincoln, T. M. (2014). No matter of etiology: Biogenetic, psychosocial and vulnerabilitystress causal explanations fail to improve attitudes towards schizophrenia. Psychiatry Research, 215(3), 753-759. doi:10.1016/j.psychres.2013.12.056
Torre, E. H. G., \& Amarante, P. (2001). Protagonismo e subjetividade: A construção coletiva no campo da saúde mental [Protagonism and subjectivity: Collective construction in the mental health field]. Ciência \& Saúde Coletiva, 6(1), 73-85. doi:10.1590/S141381232001000100006

Silvana Carneiro Maciel is a Professor of the Department of Psychology and Postgraduate in Social Psychology at Universidade Federal da Paraíba, João Pessoa-PB, Brazil.

Cicero Roberto Pereira is a Professor of the Department of Psychology and Postgraduate in Social Psychology at Universidade Federal da Paraíba, João Pessoa-PB, Brazil and Professor at Instituto de Ciências Sociais da Universidade de Lisboa.

Tiago Jessé Souza de Lima is a Professor of the Department of Psychology and Postgraduate in Administration at Universidade de Fortaleza, Fortaleza -CE, Brazil.

Luana Elayne Cunha de Souza is a Professor of the Department of Psychology and Postgraduate in Psychology at Universidade de Fortaleza, Fortaleza -CE, Brazil.

Leoncio Camino is a Professor of the Department of Psychology and Postgraduate in Social Psychology at Universidade Federal da Paraíba, João Pessoa-PB, Brazil.

Giselli Lucy Souza Silva is a candidate of the Postgraduate Program in Social Psychology at Universidade Federal da Paraíba, João Pessoa-PB, Brazil.

\section{Authors' Contribution:}

All authors made substantial contributions to the conception and design of this study, to data analysis and interpretation, and to the manuscript revision and approval of the final version. All authors assume public responsibility for content of the manuscript.

Received: Aug. 12, 2016

1st Revision: Nov. 16, 2016

2nd Revision: Jun. 22, 2017

Approved: Apr. 26, 2018

How to cite this article:

Maciel, S. C., Pereira, C. R., Lima, T. J. S., Souza, L. E. C., Camino, L., \& Silva, G. L. S. (2019). Social exclusion of the people suffering from mental disorders: A proposal for an explanatory model. Paidéia (Ribeirão Preto), 29, e2915. doi:http://dx.doi.org/10.1590/1982-4327e2915 